\title{
Pre-service Music Teachers' Metaphorical Perceptions of the Concept of a Music Teaching Program
}

\author{
Deniz Beste Çevik Kılıç \\ ${ }^{1}$ Necatibey Faculty of Education, Balıkesir University, Balıkesir, Turkey \\ Correspondence: Deniz Beste Çevik Kılıç, Necatibey Faculty of Education, Division of Fine Arts Education, \\ Department of Music Education, Balıkesir University, Balıkesir, Turkey. Tel: 90-266-241-1212. E-mail: \\ beste@balikesir.edu.tr
}

Received: March 31, 2017

Accepted: April 15, $2017 \quad$ Online Published: May 4, 2017

doi:10.5539/jel.v6n3p273

URL: http://doi.org/10.5539/jel.v6n3p273

\begin{abstract}
This study was intended to reveal pre-service music teachers' perceptions of the concept of a "music teaching program" with the use of metaphors. Its sample included 130 pre-service music teachers in the Music Teaching Program of Fine Arts Teaching Department in Balıkesir University's Education Faculty. The study data were collected by having the participants complete the sentences: "The music teaching program is like... because..." and "The music teaching program is similar to... because....". The study's qualitative data were collected using a survey form with open-ended questions. Subsequently, the data were interpreted using content analysis. The pre-service music teachers produced 30 metaphors. These metaphors were classified into six conceptual groups based on their shared aspects. The study concluded that pre-service music teachers explained the concept of a "music teaching program" using a variety of metaphors.
\end{abstract}

Keywords: metaphors for the concept of a music teaching program, music teaching programs, pre-service music teachers

\section{Introduction}

We are living in an age of information, watching rapid developments in science and technology. Thus, there is a growing need for people who do research, question and criticize things, are capable of thinking creatively, produce knowledge and use superior thinking skills such as analysis and synthesis. This creates the need for continuous personal development for all people. Education has become even more important in such an environment, and it is compulsory for education institutions to review their functions. Teacher training programs have an obvious effect on the training of teachers that will meet the necessities of their occupation professionally. In this regard, the renovation of education institutions with a structuring based on social needs and expectations is important in this continually developing and changing world (Ünal \& İlter, 2010).

There were new configurations in teacher training in Turkey in the year 1998, and this was an important beginning of development. In 2006, music teacher programs were revised along with all the other undergraduate teaching programs in education faculties (Akman \& Taşkın, 2010). The improvement of undergraduate teaching programs is necessary for teaching pre-service music teachers the knowledge and skills required in their study area and make them better qualified individuals since the quality of education is directly linked to the quality of teachers. Hence, all components of the teachers training system should be improved in order to train a sufficient number of teachers with the qualities required by current and future conditions (Azar, 2011). Quality education provided to pre-service teachers will have a major influence on their professional lives. It is certain that quality education is important in training better teachers. Researchers should be informed about pre-service teachers' feelings, perceptions, attitudes, thoughts and expectations. These are important factors that have a fundamental influence on teacher training. Studies of these factors have mainly used metaphors for their research (Noyes, 2004; Thomas \& Beauchamp, 2011). A relevant study indicated that the study of pre-service teachers' perceptions, attitudes and beliefs was one of the main objectives of teacher training studies, and the results of these studies were important since they contribute to the professional development of pre-service teachers by shaping occupational practices (Noyes, 2004).

The use of metaphors reveals how individuals think and see the world when trying to understand it. Individuals employ metaphors when describing both their own thoughts and feelings and those of the others. Metaphors are 
described as analogies, likenesses, resemblances or the expression of one entity as another (Sanchez, Barreiro, \& Maojo, 2000). Metaphor is a tool for perception itself, and it includes the transfer of knowledge from a familiar field to an unfamiliar one. In other words, a metaphor is the symbolic transformation of a thing into a completely different thing (Anderson \& Milbrandt, 2002). Longman (2015) suggested that metaphor is the description of a thing using its similarities with something else. In addition, metaphors are important in the concretization and visualization of abstract concepts when learning difficult concepts. About this point, Yob (2003) claims that metaphors are strong mental tools for understanding and explaining complex and abstract phenomena. Lakoff (2009) said that metaphors are helpful tools for revealing students' cognitive perceptions of a concept and the affective aspects of their mental images. Thus, metaphors are personal images and strong education tools that can be used for reflection. They are mirrors that are good at helping us understand the world and what happens in it (Perry \& Cooper, 2001). In this context, metaphor is one of the most important instruments in trying to comprehend partially things that we cannot comprehend as well as our feelings, aesthetic experiences, moral values and psychological structure (Lakoff \& Johnson, 2005).

Forceville (2002) stressed that three questions should be answered before accepting a thing as a metaphor: What is the subject of the metaphor, What is the source of the metaphor, and Which aspects are planned to be referred from the metaphor's source to its subject? For instance, the sentence "A teacher is like a gardener" or "A teachers resembles a gardener" uses the image of the gardener to draw attention to the similarities of a teacher to a gardener. In these sentences, "teacher" is the subject of the metaphor, and gardener is its source. The aspect of the source of the metaphor that refer to its subject is that a gardener deals with the saplings being grown individually, and a teacher takes students' individual differences into consideration (Saban, 2006).

In the past few years, there has been an increase in the number of studies that are intended to determine how individuals perceive concepts related to their areas of study using the metaphoric perception technique. Metaphors are used in almost every moment of life in all areas, and they are included in education as well, which makes them a subject for educational research. In educational research, metaphors are frequently used as educational tools to reveal the traces of concepts in people's minds with the use of different words and teach any subject (Botha, 2009). The use of metaphors in education makes it possible to learn new things and retain them in mind while improving individuals' motivation, imagination and creativity (Hogler, Gross, Hartman, \& Cunliffe, 2008; Vadeboncoeur \& Torres, 2003).

Metaphors are used to develop and plan educational programs, encourage students to learn and improve creative thinking. They can also be used for determining teachers' and pre-service teachers' occupational perceptions (Kösterelioğlu \& Bayar, 2014). A review of the studies of metaphor revealed that there are many studies that have used metaphors to determine pre-service teachers' perceptions of the concept of a teacher (Cerit, 2008; Gömleksiz, 2013; Günay, 2015; Kasoutas \& Katerina, 2009; Saban, Koçbeker, \& Saban, 2006; Zheng \& Song, 2010), their perceptions of the concept of a student (Guerrero \& Villamil, 2002; Saban, 2009), the occupational perceptions of teachers and pre-service teachers (Martinez, Sauleda, \& Huber, 2001; McEwan, 2007; Saban, 2009), perceptions of the internet (Palmquist, 1996; SSahin \& Baturay, 2013), perceptions of the concept of a principal (Ateş, 2016; Çobanoğlu \& Gökalp, 2015; Zembat, Tençeli, \& Akşin, 2015); perceptions of the concept of distance education (Özçınar \& Tuncay, 2009) and perceptions of educational programs (Aykaç \& Çelik, 2011; Gültekin, 2013). Studies of music have used metaphors to analyze music as a communication tool with the metaphorical language in musical pieces (Zangwill, 2014; Zbikowski, 2008), examined metaphor as an instructional tool in the creation and improvement of musical expression (Schippers, 2006; Woody, 2004) and determined perceptions of the concepts of music and music lessons (Umuzdaş S. \& Umuzdaş M., 2013).

To conclude, pre-service music teachers' acceptance or rejection of the new knowledge they encounter during their education process plays an important role in research about teacher training. In this regard, metaphors can be used to reveal pre-service teachers' expectations and perceptions (Cerit, 2008; Saban, 2004; Saban et al., 2006). A review of the relevant literature showed that there are no studies of the metaphors that pre-service music teachers use for the concept of a music teaching program. For this reason, the aim of this study is to use metaphors to reveal pre-service music teachers' perceptions of the concept of a music teaching program. Here are its research questions:

- What are the metaphors that pre-service music teachers use for the concept of a music teaching program?

- What categories can be created for the metaphors used by the pre-service teachers based on their shared aspects? 


\section{Materials and Methodology}

This study used "phenomenology", a qualitative research design, with the purpose of determining pre-service music teachers' perceptions of the concept of a "music teaching program" using metaphors. In the world we live in, we encounter phenomena in the forms of experience, perceptions, orientations, concepts and situations (McMillon, 2000). The aim of phenomenology is to reveal individuals' experiences and perceptions related to a certain phenomenon as well as the meanings they attribute to them (Annells, 2006). Phenomenology is the study of how people make sense of their individual or collective experiences, how they perceive and transfer them to their minds, how they describe situations and the language they use to communicate them to other people (Merriam, 2013). Phenomenological design focuses on phenomena of which we are aware, but of which we do not have a deep and detailed understanding. For this reason, phenomenology is a suitable basis for studies that analyze phenomena that are not completely unfamiliar to us, but which we still cannot fully comprehend. In phenomenological studies, data analysis is intended to reveal experiences and meanings. Thus, content analysis attempts to conceptualize the data and create categories that can describe the phenomenon. The results are presented in a descriptive manner with frequent use of direct quotations. In addition, the study findings are explained and interpreted in the framework of the categories created by the study (Yıldırım \& Şimşek, 2011).

\subsection{Study Sample}

The sample of this study included 130 pre-service music teachers from a university located in western Turkey. Of them, 79 (60.7\%) were female, and 51 (39.3\%) were male.

\subsection{Data Collection Tools}

The study data were collected in the 2017 spring semester using a survey form with open-ended questions. Before creating the data collection tool, the researcher analyzed studies that use metaphors to determine individual perceptions (Inbar, 1996; Linn, Sherman, \& Gill, 2007; Pishghadam \& Pourali, 2011; Saban, 2009). Although some of them utilized Likert-type scales, the majority asked their participants to complete open-ended sentences. Thus, the researcher initially held preliminary interviews with the participants to create the survey form and documented these conversations in writing. The pre-service music teachers were briefly informed about metaphors, their use and their purposes. They were also given examples of living and non-living things to choose as metaphors. Afterwards, the participants were asked to complete the sentences, "The music teaching program is like... because..." and "The music teaching program is similar to... because....". This was intended to determine pre-service music teachers' thoughts about the music teaching program and the reasons for them. The word "like" was used to have students build a connection between the source and subject of the metaphor, and the word "because" was used to have them produce a "justification" (or a "logical basis") for the metaphors they created (Saban, 2009). The pre-service teachers' responses were the main data source of this study.

\subsection{Data Analysis}

This study analyzed the data using survey and content analysis, both qualitative research methods. The application of the survey attempted to describe events (Karasar, 1995). This study attempted to determine the pre-service music teachers' perceptions of the concept of a "music teaching program" with the use of metaphors. The analysis and interpretation of the metaphorical expressions written by pre-service teachers were conducted in the five-stage process described by Saban (2008):

(1) naming,

(2) organization (elimination and refinement),

(3) category development,

(4) establishing validity and reliability,

(5) digitization of the data (Armstrong, Davis, \& Paulson, 2011; Saban et al., 2006; Saban, 2008).

1) Naming: In this stage, the participants' metaphors were listed, giving a code to each metaphor as well (e.g., computer, grandmother, lighthouse, compass). Answer sheets that did not include any metaphors or metaphors with no justifications were excluded from the study.

2) Organization (Elimination and Refinement): In this stage, the researcher used "metaphor analysis" techniques to divide each metaphor into its components and determine their similarities with the other metaphors (Moser, 2000). Then, the metaphors were reread and reviewed individually, and each metaphor was analyzed considering its: a) subject, b) source and c) the relationship between subject and source. The researcher also created a 
"sample metaphor list" for two main purposes: (a) using it as a reference for classifying metaphors in a certain category and (b) validating the data analysis and the interpretations of this study.

3) Category Development: In this stage, the metaphors created by the pre-service teachers were analyzed for their shared aspects in relation to the concept of a "music teaching program". The researcher created a metaphor list to see how each metaphor conceptualized the phenomenon of a "music teaching program". Each metaphor produced by the pre-service teachers was correlated to a certain theme, which created six conceptual categories.

4) Establishing Validity and Reliability: Validity and reliability are the two most important criteria for ensuring the credibility of study results: "Preparing a detailed report of the collected data and explaining how the study results were found are important criteria for validity in qualitative studies" (Yıldırım \& Şimşek, 2011). When explaining the study results, the researcher provided direct quotations from pre-service teachers' responses to the questions in survey form. To attribute the quotations, the participants were numbered from 1 to 130 , and their genders were indicated with letters. For instance, (S:9F) means (student 9, female), and (S:11M) means (student 11, male).

The researcher also consulted expert opinion to ensure the reliability of the study. Two experts in this kind of research were given two lists. The first list showed samples of the metaphors that were produced by the pre-service teachers, and the second showed the names and characteristics of six conceptual categories for the music teaching program metaphors. The experts were asked to match the sample metaphors on the first list with the six conceptual categories on the second list, leaving none of the metaphors out. Afterwards, the researcher compared the experts' matching to that of this study. The researcher determined the numbers of agreements and disagreements and calculated the reliability of the study using the formula by Miles and Huberman (1994) (reliability=agreement/agreement+disagreement). Qualitative studies are reliable at the desired level when the consistency between evaluations by experts and researchers is $90 \%$ or higher (Miles \& Huberman, 1994). The reliability of this research was $96 \%$.

5) Uploading the data: The study data were digitized, and their frequencies (f) and percentages (\%) were calculated. Then, they were prepared for interpretation by the researcher.

\section{Findings}

This section will present the findings related to the research questions. The findings will be presented in tables, and the conceptual categories that include metaphors by their shared aspects will be examined based on examples of the pre-service teachers' responses.

1) What are the metaphors that pre-service music teachers use for the concept of a "music teaching program"?

Table 1 shows an alphabetical list of the metaphors that the pre-service music teachers created for the concept of a "music teaching program" in addition to the numbers and percentages of students who used each metaphor.

Table 1. The metaphors that the pre-service music teachers created for the concept of a music teaching program, and the numbers and percentages of students who used each metaphor

\begin{tabular}{|c|c|c|c|c|c|c|c|}
\hline $\begin{array}{l}\text { Sequence of } \\
\text { the Metaphor }\end{array}$ & $\begin{array}{l}\text { Name of the } \\
\text { Metaphor }\end{array}$ & $f$ & $\%$ & $\begin{array}{l}\text { Sequence of the } \\
\text { Metaphor }\end{array}$ & Name of the Metaphor & $\mathrm{f}$ & $\%$ \\
\hline 1 & Root of a tree & 5 & 3.84 & 16 & Sculptor & 7 & 5.38 \\
\hline 2 & Brain & 3 & 2.30 & 17 & Light & 2 & 1.53 \\
\hline 3 & Computer & 5 & 3.84 & 18 & Human life & 4 & 4.61 \\
\hline 4 & Grandmother & 6 & 4.61 & 19 & Hair gel & 5 & 3.84 \\
\hline 5 & To raise a child & 7 & 5.38 & 20 & Guide & 5 & 3.84 \\
\hline 6 & Pottery & 6 & 4.61 & 21 & Puppet & 4 & 4.61 \\
\hline 7 & Ecological balance & 3 & 2.30 & 22 & Hourglass & 6 & 4.61 \\
\hline
\end{tabular}




\begin{tabular}{|c|c|c|c|c|c|c|c|}
\hline 8 & Foundation of a house & 3 & 2.30 & 23 & Blue & 1 & 0.76 \\
\hline 9 & Factory & 5 & 3.84 & 24 & Navigator & 7 & 5.38 \\
\hline 10 & Lighthouse & 6 & 4.61 & 25 & Orchestra & 5 & 3.84 \\
\hline 11 & Night light & 2 & 1.53 & 26 & Compass & 8 & 6.15 \\
\hline 12 & Travel program & 3 & 2.30 & 27 & Clock & 4 & 4.61 \\
\hline 13 & Sun & 2 & 1.53 & 28 & Venous blood vessel & 1 & 0.76 \\
\hline 14 & Solar system & 1 & 0.76 & 29 & Cook book & 6 & 4.61 \\
\hline \multirow[t]{2}{*}{15} & Dough & 3 & 2.30 & 30 & Trip & 5 & 3.84 \\
\hline & & & & Total & & 130 & 100 \\
\hline
\end{tabular}

Table 1 shows that pre-service music teachers produced 30 metaphors for the concept of a "music teaching program". The first eight metaphors are: raising a child $(\mathrm{f}=7)$, sculptor $(\mathrm{f}=7)$, navigator $(\mathrm{f}=7)$, grandmother $(\mathrm{f}=6)$, pottery $(\mathrm{f}=6)$, lighthouse $(\mathrm{f}=6)$, hourglass $(\mathrm{f}=6)$ and cook book $(\mathrm{f}=6)$. The pre-service teachers used nine living things and 21 non-living things as metaphors.

2) What categories can be created for the metaphors used by the pre-service teachers considering their shared aspects?

In this section, the metaphors created in the study will be classified into six categories which are guide, shaping, systematic whole, milestone, illuminating and process. The categories will be tabulated for interpretation.

Table 2. The distribution of pre-service teachers' metaphors in the "guide" category

\begin{tabular}{lll}
\hline Metaphor & $\mathrm{f}$ & $\%$ \\
\hline Grandmother & 6 & 4.61 \\
Lighthouse & 6 & 4.61 \\
Guide & 5 & 3.84 \\
Navigator & 7 & 5.37 \\
Compass & 8 & 6.67 \\
Cook book & 6 & 4.61 \\
Total & 38 & 29.2 \\
\hline
\end{tabular}

Table 2 shows the metaphors included in the "guide" category, and the numbers and percentages of the students who created each metaphor. The pre-service teachers created six metaphors in this category. Compass and navigator were the two most common metaphors. Considering the metaphors in this category, the music teaching program adapts to certain situations including acting as a guide and showing the way. Here are some unmodified quotations of the participants' responses:

"The music teaching program is like a grandmother. Grandmothers guide families to raise their children. The music teaching program similarly guides us for our prospective professional lives in achieving our goals" (S:36F). (The metaphor of grandmother)

"The music teaching program resembles a lighthouse because the program helps us learn about how to teach the subjects in our prospective professional lives. The music teaching program will illuminate the pre-service music teachers about how to teach subjects in the future like a lighthouse shows us the way in the dark" (S:68M). (The metaphor of lighthouse) 
"The music teaching program is like a guide because we would not know how to teach the subjects when we become professional teachers. Each teacher would teach lessons in a different way, which would cause disconnections. In this regard, the music teaching program will show the way to pre-service music teachers in the future professional lives" (S:15M). (The metaphor of guide)

"The music teaching program resembles a navigator. A navigator determines the point that we want to reach and helps us follow the way to it. Thus, the music teaching program will help pre-service teachers achieve the goals they set for themselves" (S:93M). (The metaphor of navigator)

"The music teaching program resembles a compass because this program shows pre-service music teachers the direction they should follow. Therefore, we are trained in accordance with the music teaching program" (S13M). (The metaphor of compass)

"The music teaching program resembles a cook book because a cook book informs us about the amount and sequence of the ingredients that we should use when we cook. Thus, the music teaching program will guide us about the way and time that we should teach subjects in our future professional lives" (S:38F). (The metaphor of navigator)

Table 3. The distribution of pre-service teachers' metaphors in the "shaping" category

\begin{tabular}{lll}
\hline Metaphor & $\mathrm{f}$ & $\%$ \\
\hline Pottery & 6 & 4.60 \\
Dough & 3 & 2.30 \\
Sculptor & 7 & 5.37 \\
Hair gel & 5 & 3.84 \\
Puppet & 4 & 3.07 \\
Total & 25 & 19.2 \\
\hline
\end{tabular}

Table 3 shows the metaphors included in the shaping category, and the numbers and percentages of the students who created each metaphor. The pre-service teachers created five metaphors in this category. Sculptor and pottery were the two most common metaphors. The metaphors in this category indicate that the music teaching program helps teachers shape their students, give a form to them, which means creating a direction for their future lives. For this reason, the study claims that the music teaching program is related to training pre-service teachers as qualified music teachers that will be beneficial to society. Here are some unmodified quotations of the participants' responses:

"The music teaching program resembles pottery because teachers shape the current music teaching program just like shaping pottery, and we can shape the knowledge we learned during this program with our own studies. Therefore, the better the potter is, the more useful the product will be" (S:16M). (The metaphor of pottery)

"The music teaching program resembles dough. We can reflect our own thoughts and opinions on the dough. In my opinion, this is just what the music teaching program is because the goals of programs are determined beforehand, and the products are aimed to be created in accordance with these targets" ( $\mathrm{S}: 45 \mathrm{~F}$ ). (The metaphor of dough)

"The music teaching program resembles a sculptor. The music teaching program helps shape students just like a sculptor shapes clay" (S:88M). (The metaphor of sculptor)

"The music teaching program resembles hair gel. The music teaching program shapes the school it is applied to just like hair gel gives form to hair. Music instruction can be given any form with music teaching program just like hair gel can give any form to hair" (S:11F). (The metaphor of hair gel)

"The music teaching program resembles a puppet because the holder of the puppet has the strings that can give any form to it. It is the holder who animates the puppet behind the curtain. We have the chance to make any change and give any shape to a puppet with a certain mold. Thus, the music teaching program can be shaped by certain additions and revisions" (S:23F). (The metaphor of puppet) 
Table 4. The distribution of pre-service teachers' metaphors in the "systematic whole" category

\begin{tabular}{lll}
\hline Metaphor & $\mathrm{f}$ & $\%$ \\
\hline Ecological balance & 3 & 2.3 \\
Factory & 5 & 3.83 \\
Travel program & 3 & 2.3 \\
Solar system & 1 & 0.76 \\
Orchestra & 5 & 3.83 \\
Clock & 4 & 3.06 \\
Total & 21 & 16.1 \\
\hline
\end{tabular}

Table 4 shows the metaphors included in the "systematic whole" category, and the numbers and percentages of the students who created each metaphor. The pre-service teachers created six metaphors in this category. Factory and orchestra are the two most common metaphors. Based on the metaphors included in this category, the study claims that the music teaching program is planned and purposive, and it is a whole together with all its components. Here are some unmodified quotations of the participants' responses:

"The music teaching program resembles the ecological balance because all the elements within ecological balance are correlated to each other. Everything included in the ecological balance support and complete each other just like the parts of a systematic whole, and I believe that the music teaching program is similar to this function" (S:66B). (The metaphor of ecological balance)

"The music teaching program resembles a factory because the music teaching programs enables processing the pre-service teacher (input) for a certain period, and trans him or her as a qualified music teacher (output). The program might be resembled to a factory regarding these differences" (S:28M). (The metaphor of factory)

"The music teaching program resembles a travel program. The program initially sets its goals. Then, it indicates the way and time to achieve these goals. This is very similar to the pre-determination of the routes in travel programs. They decide on their destinations, set the dates for these trips, and evaluate their acquisitions from them" (S:15F). (The metaphor of travel program)

"The music teaching program resembles the solar system. There is a systematized organization of the planets. For this reason, even 1 centimeter of change in the position of the sun might lead to undesired events in the earth. From this perspective, I believe that the music teaching program resembles the sun. The better planned and systematized the program is, the better it will function" (S:101M). (The metaphor of solar system)

"The music teaching program resembles a orchestra. The musicians in an orchestra make effort to play their instruments in a harmonious and systematized way. The music teaching program, just like an orchestra, can perform its functions when it is planned and programmed" (S:10F). (The metaphor of orchestra)

"The music teaching program resembles a clock. Clocks work in the most regular manner. We learn our location within time when we look at a clock. We can plan the process of music education with the music teaching program as we are able to plan our time using the clock" (S:31M). (The metaphor of clock)

Table 5. The distribution of pre-service teachers' metaphors in the "milestone" category

\begin{tabular}{lll}
\hline Metaphor & $\mathrm{f}$ & $\%$ \\
\hline Root of a tree & 5 & 3.85 \\
Brain & 3 & 2.31 \\
Computer & 5 & 3.85 \\
Foundation of a house & 3 & 2.31 \\
Venous blood vessel & 1 & 0.77 \\
Total & 17 & 13.1 \\
\hline
\end{tabular}


Table 5 shows the metaphors included in the "milestone" category, and the numbers and percentages of the students who created each metaphor. The pre-service teachers created five metaphors in this category. The root of a tree and a computer were the two most common metaphors. The metaphors in this category stipulate that there are essential themes that form the foundation of the music teaching program. For this reason, the researcher suggests that the music teaching program helps music education make quality progress. Here are some unmodified quotations of the participants' responses:

"The music teaching program resembles the root of a tree. Trees need their roots for healthy fruit production. Similarly, the music teaching program plays a major role in determining our needs and providing quality music education" (S:44M). (The metaphor of the root of a tree)

"The music teaching program resembles a brain. The brain is vital among all body organs that form the human body, and the music teaching program is similarly important for music instruction. Hence, I think the music teaching program resembles the brain because music teaching program is a vital part of the music instruction system" (S:9B). (The metaphor of brain)

"The music teaching program resembles a computer. We can use the computer productively when we upload beneficial programs to it. I think the music teaching program will be able to train successful music teachers as long as students are provided with quality information from the beginning" (S:66F). (The metaphor of computer)

"The music teaching program resembles the foundation of a house because we cannot build the structure if there is no foundation. In this regard, the music teaching program plays an important role in music instruction" (S:76B). (The metaphor of the foundation of a house)

"The music teaching program resembles a venous blood vessel. The music teaching program is as important to pre-service music teachers as a venous blood vessel is important to humans because the music teaching program collects and disintegrates the knowledge to be learned. Afterwards, the knowledge that is beneficial to the individual is again included in the process" (S:53M) (The metaphor of venous blood vessel)

Table 6. The distribution of pre-service teachers' metaphors in the "illuminating" category

\begin{tabular}{lll}
\hline Metaphor & $\mathrm{f}$ & $\%$ \\
\hline Night Light & 2 & 1.53 \\
Sun & 2 & 1.53 \\
Light & 2 & 1.53 \\
Blue & 1 & 0.76 \\
Total & 7 & 5.38 \\
\hline
\end{tabular}

Table 6 shows the metaphors included in the "illuminating" category, and the numbers and percentages of the students who created each metaphor. The pre-service teachers created four metaphors in this category. Night light, sun and light were the most common metaphors in this category. In other words, the pre-service teachers regard the music teaching program as the sun and as light. Here are some unmodified quotations of the participants' responses:

"The music teaching program resembles night light. It is just like a night light that tries to illuminate those who are eager to learn by informing them (S:13M). (The metaphor of night light)

"The music teaching program is like the sun. The sun warms and illuminates the earth, the music teaching program similarly warms and illuminates students by providing information to them and makes their future brighter" (S:111F). (The metaphor of sun)

"The music teaching program gives a light to students through knowledge. They learn more and gain more knowledge as they proceed in the program, which is just like a sunset" (S:99M). (The metaphor of light)

"The music teaching program resembles the color blue. It is deep just like the sea and provides endless information. The color blue can illuminate a dark environment, and the music teaching program similarly illuminates music students with information" (S:128M). (The metaphor of blue) 
Table 7. The distribution of pre-service teachers' metaphors in the "process" category

\begin{tabular}{lll}
\hline Metaphor & $\mathrm{f}$ & $\%$ \\
\hline To raise a child & 7 & 5.37 \\
Human life & 4 & 3.07 \\
Hourglass & 6 & 4.60 \\
Trip & 5 & 3.84 \\
Total & 22 & 16.9 \\
\hline
\end{tabular}

Table 7 shows the metaphors included in the "process" category, and the numbers and percentages of the students who created each metaphor. The pre-service teachers created four metaphors in this category. Raising a child and an hourglass were the most common metaphors in this category. This means that the pre-service teachers consider the music teaching program to be deep and believe that the knowledge they should learn in framework of the program is endless. In addition, the pre-service teachers stressed the importance of teaching musical knowledge in an orderly and timely manner without any hurry. Here are some unmodified quotations of the participants' responses:

"The music teaching program resembles raising a child. Families apply certain methods when raising their children. When their children display an undesired behavior, parents make up for their mistakes and try not to repeat them with their other children. Thus, current mistakes and deficiencies are observed in practice in music teaching program and eliminated later on" (S:78F). (The metaphor of raising a child)

"The music teaching program resembles human life. After individuals are born, they acquire certain characteristics in certain development stages. They adapt themselves to their environment at the beginning, and then start to get some satisfaction with their occupations later on. Music teaching program will similarly affect the musical behaviors that pre-service music teachers should learn at the end of certain processes and stages" (S:130F). (The metaphor of human life)

"The music teaching program resembles an hourglass. It determines what information to be taught in what year of the program. This way all the knowledge will be accumulated in the minds of pre-service teachers. We will be able to use this knowledge in our prospective professional lives" (S:126F). (The metaphor of hourglass)

"The music teaching program resembles a trip. It is like an endless road. It will renew itself all the way as well as the students included in it and support their continuous development" (S:103M). (The metaphor of trip)

\section{Discussion, Conclusion and Recommendations}

This study aimed to reveal pre-service music teachers' perceptions of the concept of "a music teaching program" using metaphors, and classify the metaphors they produced into conceptual categories. The metaphors were used to get information about pre-service music teachers' perspectives to their occupation, and interpret a variety of concepts including education (Aubusson, 2002; Mcdermott, 2003). Schmitt (2005) suggested that metaphors are used to make a clear presentation of qualitative study results, and reduce the complexity of the qualitative data. Patton (1990) said that metaphor is a creative strategical function that helps analyze and interpret study results. The pre-service teachers explained in this study their thoughts, perceptions, attitudes, beliefs, and past experiences about the concept of a music teaching program using metaphors.

This study tells us about pre-service teachers' perceptions of the concept of "a music teaching program". When explaining the concept of "a music teaching program", the pre-service teachers produced different metaphors such as "ecological balance, hair gel, the color blue and a venous blood vessel" in addition to familiar concepts such as "the root of a tree, grandmother, sculptor, a guide and a compass". This proves that the concept of "a music teaching program" cannot be explained with a familiar metaphor. A previous study stated that the metaphors are purposive, and participants' ways of completing the sentence "Because..." are different from each other (Saban et al., 2006). Thus, the metaphors created by pre-service teachers for the concept of "a music teaching program" in this study show that its findings are consistent with the relevant educational research in the literature (Saban, 2008; Yob, 2003).

The wide range of the metaphors created by the participants is a proof of their perspectives, creativity and the richness of their cognitive structures. The most common metaphor in the study was "compass". Raising a child $(\mathrm{f}=7)$, sculptor $(\mathrm{f}=7)$, navigator $(\mathrm{f}=7)$, grandmother $(\mathrm{f}=6)$, pottery $(\mathrm{f}=6)$, lighthouse $(\mathrm{f}=6)$, hourglass $(\mathrm{f}=6)$, and cook book $(\mathrm{f}=6)$ were the next most frequently chosen metaphors. The study evaluated the metaphors produced 
by the pre-service teachers and found that they expressed positive aspects of the music teaching program. It is very important that the pre-service teachers created positive and not negative metaphors, for their program of study.

The metaphors "brain, computer, factory, lighthouse, travel program, sun and compass" were also created in a study by Özdemir (2012). In a study by Taşdemir and Taşdemir (2011), the teachers produced 307 metaphors for dimensions of the primary and middle school curricula. In this study, the metaphors "the root of a tree" and "computer" hat the participants created for music teaching program were consistent with those created in Taşdemir and Taşdemir's (2011) study. A relevant study is also consistent with this study in terms of the metaphors "the foundation of a house" and "compass" that were created for the music teaching program (Semerci, 2007). The researcher believes that the results of this study are consistent with the relevant literature; however, this study collected the results in a variety of categories in a more comprehensive manner. In addition, this study revealed that the pre-service music teachers produce positive metaphors for the concept of a music teaching program. On the other hand, the educational studies conducted with in-service and pre-service teachers usually find that they create negative metaphors (Aykaç \& Çetin, 2011; Taşdemir \& Taşdemir, 2011). The results related to the negative metaphors that were created by participants are not consistent with the findings of this study.

According to the results of this study, the illumination and process categories included fewer metaphors than the other categories. This result implies that the pre-service teachers adopted the metaphors in the other categories more than these ones. The study formed six categories based on the metaphors that the pre-service teachers created for the music teaching program. These categories are "guide, shaping, a systematic whole, milestone, illuminating and process". A relevant study found the categories "guide, process and a mold that shapes individuals", which are similar to some categories in this study (Özdemir, 2012). In addition, "guide" and "a systematic whole" included the most categories of all the categories created by this study. The findings of this study support those of relevant research (Nalçacı \& Bektaş, 2012).

The research findings imply that the pre-service teachers emphasize the directing aspect of the music teaching program in the guide category. The most common metaphor in this category was "compass". This indicates the fact that the pre-service teachers perceived the music teaching program as a supporting guide that shows them the way. The findings of a relevant study support the findings of this study (Gültekin, 2011; Günay, 2015). Cook-Sather (2003) said that the stereotypical thoughts that shape the structure of education systems focus on the basic metaphor, which is usually the guide. Another study found that guide or director was the first metaphor that was created by the students from different study areas for the concept of "teaching program" (Satan, 2013). The results of this study are consistent with that finding.

Another finding of this study is the shaping category. The metaphors created by the pre-service teachers in this category also prove that the music teaching program is shaped in accordance with pre-determined goals. Thus, the researcher believes that participants regarded the shaping category as a mold that shaped students with similar knowledge and skills. A previous study supports this finding (Gültekin, 2011; Yıldırım, Ünal, \& Çelik, 2011). Saban (2004) stated that the pre-service teachers saw the figure of teacher as a sculptor. This finding also supports this study. In the systematic whole category, which was another finding of the study, the pre-service teachers compared the music teaching program to a systematic structure that involved certain elements as well as correlated, planned and purposive components. In this category, the pre-service music teachers indicated that the music teaching program was a whole that affected, distributed and formed its own parts just like a factory or the ecological balance. These results are consistent with the other studies in the relevant literature (Gültekin, 2011; Schubert, 1986; Wahyudi, 2007).

The metaphors created by the pre-service teachers for the milestone category revealed that they emphasized the essential and foundational quality of the music teaching program for music education. In this context, the researcher believes that the pre-service teachers were fully aware of the importance of music teaching process in the education and training process. This shows the need to train pre-service teachers in a way that teaches them all they need to know to become qualified music teachers. A relevant study supports this finding (Koç, 2014). Another finding of the study is the illumination category, which pictures the purpose of the music teaching program as illuminating pre-service teachers and lighting their way. The "illumination" category, which is one of the conceptual categories created by Gür (2012), is included in the headings that were determined by this study. Therefore, the results of this study are consistent with that finding.

Another finding of the study indicated that the pre-service music teachers regarded music teaching program as a process. In this category, the pre-service teachers made an attempt to build a correlation between the concept of 
process and the need to learn the required knowledge, skills and competencies in certain stages in a certain timeframe. A relevant study found that the knowledge, skills and competencies that pre-service teachers learned during their undergraduate education played a primary role in the development of their professional identities (Thomas \& Beauchamp, 2011). This result is consistent with this study's findings.

To conclude, metaphor is a conceptual tool that pre-service teachers use to make sense of their thoughts, which helps determine their beliefs (Mahlios, Massengill-Show, \& Bary, 2010). This study has revealed that the metaphors that pre-service teachers produced for the concept of a music teaching program are important tools to learn about their perceptions. It also found that the pre-service teachers mainly correlated the concept of a music teaching program with non-living things and explained it with positive metaphors, and they had positive perceptions of the concept. Beck (2001) claims that metaphors make it easier to understand the subjects that are not comprehended well and focused on the importance of being informed about pre-service teachers' thoughts and perceptions of the concept of education program. The results of this study are consistent with that finding. For this reason, pre-service teachers should understand and internalize the concept of metaphor and be capable of using it in their professional lives. A quality music teaching program is important for music teachers who will educate future generations. Based on these results, the researcher suggests that:

- Researchers should attempt to develop pre-service and in service teachers' thoughts with the use of metaphors, and metaphors should be used as supporting tools in the instruction of abstract subjects.

- Similar studies should be conducted with pre-service teachers in various study areas, and their opinions about undergraduate teaching programs should be compared using metaphors.

- Alumni monitoring programs should be planned to revise teacher training programs based on their suggestions.

- Comparative studies should be planned to determine the opinions of music teachers who have graduated from the same music teaching program.

- Future studies should be conducted with larger samples and include in-service teachers as well, which will presumably make an important contribution to this area of study.

\section{References}

Akman, B., \& Taşkın, N. (2010). Türkiye'de ve dünyada okul öncesi öğretmeni yetiştirme alanındaki uygulamalar ve gelişmeler. In Geçmişten geleceğe okul öncesi eğitim. MEB Yayınları.

Anderson, T., \& Milbrandt, M. K. (2002). Art for life. Authentic instruction in art. New York: McGraw-Hill.

Annells, M. (2006). Triangulation of qualitative approaches: Hermeneutical phenomenology and grounded theory. Journal of Advanced Nursing, 56(1), 55-61. https://doi.org/10.1111/j.1365-2648.2006.03979.x

Armstrong, S. L., Davis, H. S., \& Paulson, E. J. (2011). The subjectivity problem: Improving triangulation approaches in metaphor analysis studies. International Journal of Qualitative Methods, 10(2), 151-163. https://doi.org/10.1177/160940691101000204

Ateş, T. Ö. (2016). Öğrencilerin öğretmen ve okul metaforları. International Journal of Contemporary Educational Studies, 2(1), 78-93.

Aubusson, P. (2002). Using metaphor to make sense and build theory in qualitative analysis. The Qualitative Report, 7(4), 1-14.

Aykaç, N., \& Çelik, Ö. (2011). Öğretmenlerin ve öğretmen adaylarının eğitim programına ilişkin metaforik algılarının karşılaştııılması. In I. Uluslararası Eğitim Programları ve Öğretim Kongresi. 5-8 Ekim 2011, Eskişehir.

Azar, A. (2011). Türkiye'deki öğretmen eğitimi üzerine bir söylem: Nitelik mi, nicelik mi. Yüksekögretim ve Bilim Dergisi, 1(1), 36-38.

Beck, C. R. (2001). Matching teaching strategies to learning style preferences. The Teacher Educator, 37(1), 1-15. https://doi.org/10.1080/08878730109555276

Botha, E. (2009). Why Metaphor Matters in Education. South African Journal of Education, 29, 431-444.

Cerit, Y. (2008). Öğretmen kavramı ile ilgili metaforlara ilişkin öğrenci, öğretmen ve yöneticilerin görüşleri. Türk Ë̆itim Bilimleri Dergisi, 6(4), 693-712.

Cook-Sather, A. (2003). Movements of mind: The Matrix, metaphors and re-imagining education. Teachers College Record, 105, 946-977. https://doi.org/10.1111/1467-9620.00274 
Çobanoğlu, N., \& Gökalp, S. (2015). Öğretmen adaylarının okul müdürüne ilişkin metaforik algıları. Mustafa Kemal Üniversitesi Sosyal Bilimler Enstitüsü Dergisi, 12(31), 279-295.

Forceville, C. (2002). The identification of target and source in pictorial metaphors. Journal of Pragmatics, 34, 1-14. https://doi.org/10.1016/S0378-2166(01)00007-8

Guerrero, M., \& Villamil, S. (2002). Metaphorical conceptualizations of ESL teaching and learning. Language Teaching Research, 6, 95-120. https://doi.org/10.1191/13621688021r101oa

Gültekin, M. (2011). İlköğretim öğretmenlerinin eğitim programına yükledikleri metaforlar. In I. Uluslararası Eğitim Programlarl ve Öğretim Kongresinde sunulan bildiri. Eskişehir, Türkiye.

Gültekin, M. (2013). İlköğretim öğretmen adaylarının eğitim programı kavramına yükledikleri metaforlar. Education, 38, 169.

Günay, R. (2015). Eğitim fakültesinde görev yapan öğretim elemanlarının yapılandırmacı öğretmen algıları. İlkögretim Online, 14(1), 845-861.

Gür, H. (2012). Öğretmen adaylarının öğretmen ve öğretmenlik mesleği ile ilgili metaforları: Kosova örneği. e-Journal of New World Sciences Academy (NWSA), 7(3), 885-897.

Hogler, R., Gross, M. A., Hartman, J. L., \& Cunliffe, A. L. (2008). Meaning in organizational communication: Why metaphor is the cake, not the icing. Management Communication Quarterly, 21, 393-412. https://doi.org/10.1177/0893318907309929

Inbar, D. (1996). The free educational prison: Metaphors and images. Educational Research, 38(1), 77-92. https://doi.org/10.1080/0013188960380106

Karasar, N. (1995). Araştırmalarda rapor hazırlama. 10. Baskı, Ankara: Nobel Yayın Dağıtım Ltd.

Kasoutas, M., \& Katerina, M. (2009). Exploring greek teachers' beliefs using metaphors. Austrailan Journal of Teacher Education, 34(2), 64-83.

Kösterelioğlu, İ., \& Bayar, A. (2014). Türk eğitim sisteminin sorunlarına ilişkin güncel bir değerlendirme. International Journal of Social Science, 25-I, 177-187. https://doi.org/10.9761/jasss2279

Lakoff, G. (2009). The political mind: A cognitive scientist's guide to your brain and its politics. New York: Penguin Books.

Lakoff, G., \& Johnson, M. (2005). Metaforlar hayat. İstanbul: Paradigma Yayınları.

Linn, G. B., Sherman, R., \& Gill, P. B. (2007). Making meaning of educational leadership: The principal ship in metaphor. NASSP Bulletin, 91(2), 161-171. https://doi.org/10.1177/0192636507302095

Longman Dictionary of Contemporary English. (2016). Metaphor. Retrieved September 15, 2016, from $\mathrm{http}: / / \mathrm{www} . l d o c e o n l i n e . c o m / d i c t i o n a r y / m e t a p h o r$

Mahlios, M., Massengill-Shaw, D., \& Barry, A. (2010). Making sense of teaching through metaphors: A review across three studies. Teachers and Teaching: Theory and Practice, 16(1), 49-71. https://doi.org/10.1080/13540600903475645

Martinez, M. A., Saulea, N., \& Huber, G. L. (2001). Metaphors as blueprints of thinking about teaching and learning. Teaching and Teacher Education, 17, 965-977. https://doi.org/10.1016/S0742-051X(01)00043-9

Mcdermott, P. K. (2003). Zen and the art systems of analysis: Meditations on computer system development. Lincoln: Writers Club Press.

McMillan, J. H. (2000). Educational research: Fundamentals for the consumer. New York: Longman.

Merriam, S. B. (2013). Nitel araştırma desen ve uygulama için bir rehber (Çev. S. Turan). Ankara: Nobel Yayıncilık.

Miles, M. B., \& Huberman, A. M. (1994). Qualitative data analysis. Thousand Oaks, CA: Sage.

Moser, K. S. (2000). Metaphor Analysis in Psychology-Method, Theory and Fields of Application. Forum. Qualitative Research, 1(2).

Noyes, A. (2004). Producing mathematics teachers: A sociological perspective. Teaching Education, 15(3), 243-256. https://doi.org/10.1080/1047621042000257180

Özçınar, Z., \& Tuncay, N. (2009). Distance education students' "metaphors". Procedia Social and Behavioral Sciences, 1, 2883-2888. https://doi.org/10.1016/j.sbspro.2009.01.513 
Özdemir, S. M. (2012). Eğitim programı kavramına ilişkin öğretmen adaylarının metaforik algıları. Kuramsal Eğitim Bilimleri Dergisi, 5(3), 369-393.

Palmquist, R. A. (1996). The search for an internet metaphor: A comparison of literatures.Proceedings of the American Society for Information Science, 33, 198-202.

Patton, M. Q. (1990). Qualitative Evaluation and Research Methods. CA: Sage Publications.

Perry, C., \& Cooper, M. (2001). Metaphors are good mirrors: Reflecting on change for teacher educators. Reflective Practice, 2(1), 41-52. https://doi.org/10.1080/14623940120035514

Pishghadam, R., \& Pourali, S. (2011). Metaphorical analysis of Iranian MA Students' beliefs: A qualitative study. Higher Education Studies, 1(1), 27-37. https://doi.org/10.5539/hes.v1n1p27

Saban, A. (2004). Giriş düzeyindeki sınıf öğretmeni adaylarının "öğretmen” kavramına ilişkin ileri sürdükleri metaforlar. Türk Eğitim Bilimleri Dergisi, 2(2), 131-155.

Saban, A. (2006). Lisansüstü ögrencilerin nitel araştırma metodolojisine iliş̧kin algıları, XV. Ulusal Eğitim Bilimleri, 13-15 Eylül 2006, Muğla.

Saban, A. (2008). Okula ilişkin metaforlar. Kuram ve Uygulamada Eğitim Yönetimi, 14(55), 459-496.

Saban, A. (2009). Öğretmen adaylarının öğrenci kavramına ilişkin sahip olduğu metaforlar. Türk Eğitim Bilimleri Dergisi, 7(2), 281-326.

Saban, A., Koçbeker, B. N., \& Saban, A. (2006). Öğretmen adaylarının öğretmen kavramına ilişkin algılarının metafor analizi yoluyla incelenmesi. Kuram ve Uygulamada Eğitim Bilimleri, 6(2), 461-522.

Sanchez, A., Barreiro, J. M., \& Maojo, V. (2000). Desing of virtual reality systems for education: Acognitive approach. Education and Information Technologies, 5(4). https://doi.org/10.1023/A:1012061809603

Satan, A. (2013). Öğretmen adayı öğrencilerin psikolojik danışman ilişkin metaforik algılarının incelenmesi. Sakarya Üniversitesi Eğitim Fakültesi Dergisi, 26, 64-92.

Schippers, H. (2006). As if a little bird is sitting on your finger... Metaphor as a key instrument in training Professional musicians. International Journal of Music Education, 24, 209-217. https://doi.org/10.1177/0255761406069640

Schmitt, R. (2005). Systematic metaphor analysis as a method of qualitative research. The Qualitative Report, 10(2), 358-394.

Schubert, W. H. (1986). Images of the curriculum. Portrayal: Curriculum field. In W. H. Schubert (Ed.), Curriculum: Perspective, paradigm, and possibility (pp. 25-35). New York: Macmillan.

Semerci, Ç. (2007). Program geliştirme kavramına ilişkin metaforlarla yeni ilköğretim programlarına farklı bir bakış. Cumhuriyet Üniversitesi Sosyal Bilimler Dergisi, 31(2), 125-140.

Şahin, Ş., \& Baturay, M. H. (2013). Ortaöğretim öğrencilerinin internet kavramına ilişkin algılarının değerlendirilmesi: Bir metafor analizi çalışması. Kastamonu Eğitim Dergisi, 21(1), 177-192.

Taşdemir, M., \& Taşdemir, A. (2011). Teachers' metaphors on K-8 curriculum in Turkey 'Ilköğretım programı üzerine öğretmen metaforları". In 2nd International Conference on New Trends in Education and their Implications (pp. 795-809). Antalya-Turkey.

Thomas, L., \& Beauchamp, C. (2011). Understanding new teachers' professional identities through metaphors. Teacher and Teacher Education, 27, 762-769. https://doi.org/10.1016/j.tate.2010.12.007

Umuzdaş, S., \& Umuzdaş, M. S. (2013). Sınıf öğretmenliği öğrencilerinin müzik dersine ilişkin algılarının metafor yoluyla belirlenmesi. Uluslararası Insan Bilimleri Dergisi, 10(1), 719-729.

Ünal, Ç., \& İlter, İ. (2010). Sınıf öğretmeni adaylarının lisansüstü eğitime olan tutumları (Fırat, Erzincan ve İnönü Üniversitesi Sınıf Öğretmenliği ABD örneği). Atatürk Üniversitesi Sosyal Bilimler Enstitüsü Dergisi, 14(2), 1-18.

Vadebocoeur, J. A., \& Torres, M. Y. (2003). Constructing cultural politics of education. Carfax Publishing, 24(1).

Wahyudi, W. (2007). Using metaphors to explore teachers' perceptions of school science curriculum: An Indonesian lower secondary schools case. Paper presented at the Second International Conference on Science and Mathematics Education, Penang, Malaysia. Retrieved September 17, 2016, from http://www.recsam.edu.my/cosmed/cosmed07/AbstractsFullPapers2007/ SCIENCE\%5CS040F.pdf 
Woddy, R. H. (2004). Advanced music students' use of imagery and metaphor-based instruction in generating expressive performance (pp. 482-485). ICMPC38 Evanston, IL, USA.

Yıldırım, A., \& Şimşek, H. (2011). Sosyal bilimlerde nitel araştırma yöntemleri (8. Baskı). Ankara: Seçkin Yayıncilik.

Yıldırım, A., Ünal, A., \& Çelik, M. (2011). Öğretmen kavramına ilişkin öğretmen, yönetici ve müfettiş algılarının analizi. Uluslararası İnsan Bilimleri Dergisi, 8(2), 92-109.

Yob, I. M. (2003). Thinking constructively with metaphors. Studies in Philosophy and Education, 22, 127-138. https://doi.org/10.1023/A:1022289113443

Zangwill, N. (2014). Music, metaphor and aesthetic concepts. The Journal of Aesthetics and Art Criticism, 72(1), $1-11$.

Zbikowski, L. (2008). Metaphor and music. In R. W. Gibbs Jr. (Ed.), The Cambridge Handbook of Metaphor and Thought (pp. 502-524). Cambridge: Cambridge University Press. https://doi.org/10.1017/CBO9780511816802.030

Zembat, R., Tençeli, İ. H., \& Akşin, H. (2015). Okul öncesi öğretmen adaylarının "okul yöneticisi” kavramına ilişkin algılarına yönelik metafor çalışması. Hacettepe University Faculty of Healht Sciences Journal, 1(2), 446-459.

Zheng, H. B., \& Song, W. J. (2010). Metaphor analysis in the educational discourse: A critical review. Online Submission, 8, 42-49.

\section{Copyrights}

Copyright for this article is retained by the author(s), with first publication rights granted to the journal.

This is an open-access article distributed under the terms and conditions of the Creative Commons Attribution license (http://creativecommons.org/licenses/by/4.0/). 